\title{
MILHARES DE BRAÇOS ÚTEIS: O TRABALHO INDÍGENA NA MANAUS PROVINCIAL (1858-1880)*
}

Bruno Miranda Braga**

\section{RESUMO:}

O artigo apresenta aspectos do uso da mão de obra indígena na cidade de Manaus durante o período provincial. Abordaremos a presença dos índios em termos institucionais, apresentamos como o viver da cidade fez do índio uma nova categoria urbana, a de trabalhadores, e como estes exerciam diversos ofícios no fazer da cidade da borracha. Mostraremos as resistências desses sujeitos e suas práticas na lógica cotidiana da cidade, seus diversos usos na esfera pública.

Palavras-chave: Índios; Cidade; Trabalho.

\section{ABSTRACT:}

The article presents aspects of the use of Indian labor in the city of Manaus during the provincial period. We will discuss the presence of Indians in institutional terms, we present how the live of the city made the Indian a new urban workers ' category, and how they exercised various crafts at make of the city. We'll show you the elements of these subjects and their practices in everyday logic of the city, its various uses in the public sphere.

Keywords: Indians; Town; Job.

\section{Um problema Provincial: escassez de mão de obra}

Com a belle époque em andamento, um antigo problema da Província, voltou a ser alvo das discussões políticas: a escassez da mão de obra. Otoni Mesquita, diz que o grande atrativo que desencadeou a exploração da Amazônia foi a "fartura de braços", ou seja, a demasiada quantidade de pessoas para escravizar, assim, os dominadores realizavam as três formas de estabelecer controle sobre o indígena, o descimento, o resgate ou as guerras justas e assim, justificavam ou mantinham a escravização do índio.

Desde a colonização o índio foi utilizado como mão de obra, mas, é claro, contra sua vontade e exercia este serviço, pois era obrigado a fazê-lo. Na segunda metade do século XIX,

\footnotetext{
* Parte modificada do Capítulo 3 da minha dissertação de Mestrado em História Social intitulada: Manáos uma Aldeia que virou Paris: Saberes e Fazeres Indígenas na Belle Époque Baré 1845-1910, defendida em 2016, no PPGH-UFAM.

** Mestre em História Social pelo Programa de Pós-Graduação em História da Universidade Federal do Amazonas-UFAM. Licenciado em História pelo UNINORTE-Laureate, e Licenciado em Geografia pela Universidade do Estado do Amazonas -UEA. E-mail: brunomirandahistor@hotmail.com. Atualmente é Professor Substituto na Universidade Federal do Amazonas - UFAM, no Departamento de História.
} 
não foi diferente, porém, os índios resistiam à essa imposição de várias maneiras. Vale destacar que o poder usava o discurso do trabalho como uma forma de ligar o índio ao selvagem, ao herege, pois por não ser de sua cultura exercer a função de trabalhador, esse índio foi ligado ao ócio, à vadiagem, a vagabundagem, e essas características eram condenadas pela sociedade, pois a Igreja, normatizava que o não-trabalho era pecado.

O índio sempre resistiu aos valores políticos do branco, não por ser um "selvagem ou incivilizado", porém havia a resistência com o intuito de preservar suas práticas, com o trabalho não foi diferente, uma vez que o hábito do trabalho seriado e repetitivo não era típico de sua cultura. Mesmo os que aderiram ao trabalho, constituindo neste momento a classe trabalhadora, foram marginalizados, pois a sociedade, via os trabalhadores como “promíscuos, viciosos e vagabundos e era a partir destes pressupostos que procurava enquadrá-los. Os trabalhadores reagiam de diferentes formas a estas exclusões e marginalizações."1

A esse grupo de trabalhadores indígenas, juntou-se alguns vindos de outras localidades, principalmente do Nordeste Brasileiro, impulsionados pelo discurso do enriquecimento fácil e o sonho do eterno retorno a sua pátria, no entanto, aqui encontraram outra realidade. ${ }^{2}$ E para os índios, da colonização para o fim da Província pouco mudou, à medida que,

[...] a escravização do índio, no século XIX, continuou tão frequente como nos anteriores, apesar de formalmente "abolida" desde os tempos do marquês de Pombal. John Hemming, em seu livro Amazon frontier, mostra como a escravização do índio continuou sendo praticada em quase todas as suas formas anteriores, coloniais: apresamento direto; compra e venda; estímulo às guerras intertribais. ${ }^{3}$

Logo, ao índio ainda prevaleceu o domínio pela força da cruz ou da espada, e este sobreviveu a isso e, com práticas de ressignificação, manteve-se exercendo sua cultura de forma silenciada. O trabalho indígena foi fundamental para erguer os grandes prédios públicos, para concretizar o projeto embelezador da belle époque em Manaus. Uma das formas de resistência mais praticadas durante esse período por parte dos índios, foi o abandono, do seu emprego, sem sequer receber os salários de seu direito, e essa prática,

\footnotetext{
1 LANNA, Ana Lúcia Duarte. Uma Cidade na Transição: Santos: 1870-1913. São Paulo: Editora HUCITEC/Prefeitura Municipal de Santos, 1996p. 169.

${ }^{2}$ A realidade aqui encontrada, foi chamada de "Inferno Verde". O nordestino, aqui recebeu o nome de "arigó", já vinha devendo a sua passagem, para sua sobrevivência, deveria comprar gêneros alimentícios no armazém, e sua dívida nunca diminuía. Ganhava salários mínimos, vivia em condições insalubres e perigosas no meio da floresta amazônica.

${ }^{3}$ LENONARDI, Victor. Entre Árvores e Esquecimento: História Social nos Sertões do Brasil. Brasília: Editora da UNB/Paralelo 15 editores, 1996, p. 86.
} 
sustentava ainda mais a visão etnocêntrica sobre o índio, uma vez que "o fato de abandonarem o trabalho sem receber o salário é considerado como falta de ambição.”^4

Ao analisarmos os relatórios dos Presidentes de Província e dos Governadores, observamos que a questão do trabalho sempre reincidiu sobre a questão de um corpo de trabalhadores que se incumbisse de auxiliar na construção dos edifícios públicos que surgiam aos poucos na cidade que passava por uma reurbanização.

Como primeira grande obra arquitetônica erguida na Província, o templo da Catedral de Nossa Senhora da Conceição, foi o primeiro passo para uso da mão de obra indígena em grande escala na cidade de Manaus. Segundo dados do historiador Mário Ypiranga, foi pelo suor e sangue de negros e indígenas que as pedras da Igreja foram lavadas. O autor apresentanos uma análise do ano de 1872 onde o diretor de obras públicas em seu relatório mostra-nos pouco a participação de africanos mesmo os livre. Contudo, o trabalho indígena é demasiado, na medida em que:

[...] é urgente informar que os índios vez em quando surgem, em grupos, trazidos de longe, a fim de trabalharem nas diversas obras públicas, inclusive na da matriz. E nesta altura vieram, por exemplo, elementos das aldeias de Canumã, Abacaxis, Uaraná, São Gabriel e Rio Branco[... $]^{5}$

Neste excerto percebemos como os indígenas estavam presentes no corpo de trabalhadores da cidade, e mais, percebemos a diversidade e a miscelânea cultural, só acima elencados temos cinco diferentes culturas indígenas, possivelmente haviam muitas mais trabalhando nas obras públicas da cidade.

De acordo com Patrícia Sampaio,

No século XIX, as populações indígenas estavam subordinadas a um extenso corpus legislativo que possuía importantes variações regionais. A partir de 1845, havia sido criada uma legislação imperial, o Regulamento acerca das Missões de Catequese e Civilização dos Índios (1845-1889), considerada como a "lei indigenista básica de todo o período imperial". Contudo, desde os anos de 1830, as províncias criaram normas próprias para tratar das populações indígenas dos seus territórios e isto fez com que, no Amazonas e no Pará, por exemplo, coexistissem legislações distintas para regular o acesso ao trabalho indígena: o Corpo de Trabalhadores (1838-1866), legislação que criou estruturas militarizadas de recrutamento masculino para o serviço público/particular e o Regulamento acerca das Missões, que instituiu as Diretorias de Índios, dirigidas por funcionários públicos e com apoio da Igreja, para conduzir o processo de civilização dos índios, disciplinando o acesso às suas terras e à mão de obra . $^{6}$

\footnotetext{
${ }^{4}$ DIAS, Edinea Mascarenhas. A Ilusão do Fausto: Manaus, 1890-1920. $2^{\mathrm{a}}$ ed. Manaus: Valer, 2007. p. 32.

${ }^{5}$ MONTEIRO, Mário Ypiranga. A Catedral Metropolitana de Manaus (sua longa história). Manaus: Edições Muiraquitã, 2012. p.p. 73, 74.

6 SAMPAIO, Patrícia Melo. "Educação, trabalho e diversidade étnica: Educandos Artífices e Africanos livres na Amazônia, século XIX. " In: COELHO, Wilma de Nazaré Baia e COELHO, Mauro Cézar (Orgs) Trajetórias da diversidade na Educação: formação, patrimônio e identidade. São: Editora Livraria da Física, 2012, pp. 19-50.
} 
Mas se integrar ao corpo de trabalhadores era oportuno aos indígenas como se pregava o discurso oficial, porque esses elementos não se enquadravam, não se estabeleciam de vez nas atividades dos diferentes ofícios que a cidade necessitava? Cremos que o discurso nem sempre era favorável como dizia ser, ou que ser prometido ou discutido no Relatório do Presidente de Província, não significa que fora cumprido. Sendo assim, é claro que os indígenas não se firmavam nos ofícios por aqui por essencialmente dois motivos que iremos apresentar a seguir. A primeira razão obviamente era o não cumprimento dos direitos desses trabalhadores. Salários, alimentação e auxílio a enfermidades muitas vezes figuram entre as promessas nos relatórios, mas, se há muito abandono, fuga do trabalho, simboliza que algo não estava sendo prontamente cumprido por parte dos contratantes. Devemos romper a ideia equivocada que o indígena aceitava tudo imposto com uma postura bestializada ${ }^{7}$, mas com uma postura de ação, estratégia e resistência.

A segunda razão é a mais relevante e enquadra-se perfeitamente na nossa análise que parte do pressuposto cultural. Apontamos como outra razão a não adaptação mesmo se mestiçando aos fazeres da cidade. Especialmente nos hábitos alimentares. Mário Ypiranga nos informa que da leva de trabalhadores indígenas acima citada, um "oriundo do Rio Branco, faleceu no barraco das obras e dois na enfermaria militar, vítimas de febre ou disenteria.

\begin{abstract}
"A febre ocorrera por mudanças advindas com o trabalho forçado e repetitivo aos quais o índio passara a ser integrado, as enfermidades, foram acumuladas por uma alimentação diferenciada pois, "também os índios trabalhadores não se davam bem com a alimentação salgada acostumados a comer carne e peixe sem sal."
\end{abstract}

Podemos também acreditar que os salários prometidos não eram condizentes com o trabalho exercido, bem como com as usurpações aos quais os indígenas estavam submetidos na cidade da borracha. Manaus ao se "embelezar", produzia um espaço de segregação social na qual a classe trabalhadora era atrelada ao feio, ao sujo, e ao hostil. Com essa classe sendo composta de indígenas, essa visão somente se agravava. Lembramos que a situação dos índios trabalhadores do período era uma perfeita tradução de trabalho compulsório ${ }^{9}$ que era praticado no Brasil desde a época da colonização portuguesa, pois na colônia:

\footnotetext{
7 Bestializada é uma expressão clássica da historiografia brasileira introduzida pelo historiador José Murilo de Carvalho ao analisar a participação popular na instalação da República no Brasil ao fim do século XIX. Ler mais sobre o conceito em: CARVALHO, José Murilo de. Os bestializados: o Rio de Janeiro e a República que não foi. São Paulo: Companhia das Letras, 1987.

8 MONTEIRO, 2012, Op. cit., p. 74.

${ }^{9}$ Entendemos por trabalho compulsório aquele no qual, um indivíduo ou grupo é forçado a fazer alguma espécie de trabalho, através de ameaças. Estes mesmos trabalhadores podem passar por situações de humilhação e menosprezo por não cumprimento de suas tarefas, os trabalhadores sofrem consequências físicas ou psicológicas.
} 
Podemos distinguir duas tentativas básicas de sujeição dos índios por parte dos portugueses. Uma delas, realizada pelos colonos segundo um frio cálculo econômico, consistiu na escravização pura e simples. A outra foi tentada pelas ordens religiosas, principalmente pelos jesuítas, por motivos que tinham muito a ver com suas concepções missionárias. Ela consistiu no esforço em transformar os índios, através do ensino, em "bons cristãos", reunindo-os em pequenos povoados ou aldeias. Ser "bons cristão" significava também adquirir os hábitos de trabalho dos europeus, com o que se criaria um grupo de cultivadores indígenas flexível às necessidades da Colônia. $^{10}$

Com relação aos salários desses trabalhadores, a documentação aponta que seus honorários eram pagos pelo poder público em dia e com os direitos que lhe eram prometidos. A partir de 1872, vê-se uma há uma alteração no valor recebido, e no acréscimo da alimentação entre os benefícios.

[...] O salário desses trabalhadores se regulava pelo padrão comum, mas para evitarem-se deserções só o recebiam no dia de dispensa da obra. Percebiam [sic. ] uma diária de $1 \$ 380$ réis. (Cr\$ 1,38), sem comida, tendo vigorado esse padrão até fim de maio. A partir de junho de 1872, percebiam [sic. ] $1 \$ 000$ réis $(\mathrm{Cr} \$ 1,00)$ diários com as refeições. Esses índios eram recrutados às aldeias com um fim muito utilitário de incorporá-los à civilização, fazêlos tomar contato com a sociedade e com o trabalho que enobrece, visto como a maioria deles vivia da exploração e do álcool, quando nas vilas. Eram empregados nas obras apenas durante dois ou três meses, quando saíam dispensados, levando os salários a que faziam jus. ${ }^{11}$

Uma discussão importante de percebermos contida nas entrelinhas da documentação do período, especialmente nos jornais e nos Relatórios dos Presidentes de Província, é com relação a vinda de indígenas para trabalhar nas obras de Manáos $^{12}$, como se por aqui já não existissem indígenas. No século XIX havia uma classificação evolutiva com relação a civilização. Os indígenas que residiam em Manaus eram considerados civilizados, porém, era necessário expelir a civilização aos confins do Amazonas, era preciso civilizar o "sertão de bárbaros." 13

Essa ideia remete a uma questão muito recorrente da historiografia celebrativa, a ideia de centro e margem, onde "[...] a margem, [...] inclina-se para o lado da civilização, enquanto o centro associa-se ao sedentarismo, ao desterro e ao não confinamento. O centro, além do

\footnotetext{
${ }^{10}$ FAUSTO, Boris. História do Brasil. $6^{a}$ ed. São Paulo: Editora da Universidade de São Paulo, 1998. p. 48.

${ }^{11}$ MONTEIRO, 2012. Loc. Cit.

${ }^{12}$ Utilizaremos em alguns momentos o nome Manáos para destacar que a cidade naquele momento era algo muito distante do que temos hoje. O título "Manáos" ao mesmo que designa o grupo étnico belicoso e populoso que habitara o Rio Negro, também se refere a uma improvisação, uma forma de apresentar que a cidade estava mudando, e que os índios, haviam ficado apenas na memória das origens da cidade. Coisa que sabemos era apenas um almejo da sociedade enriquecida e exterior que veio residir na cidade no final do XIX com a produção da goma elástica.

${ }^{13}$ A expressão é do historiador Auxiliomar Silva Ugarte. In: UGARTE, Auxiliomar Silva. Sertões de Bárbaros. O Mundo Natural e as Sociedades Indígenas da Amazônia na Visão dos Cronistas Ibéricos (Séculos XVI-XVII). 1. ed. Manaus: Editora Valer, 2009.
} 
mais, remete à ideia de estagnação, enquanto a margem revela a presença do espírito empreendedor"14. Assim, Manaus atuaria como polo difusor de civilização, como a margem, e, as regiões mais distantes da Província seriam o centro, e destas vinham os indígenas para realizarem os misteres no mundo do trabalho no qual a cidade estava envolta.

Na Amazônia Portuguesa, a partir de 1757 com a decretação do Diretório Pombalino, ${ }^{15}$ passou a haver uma distribuição da mão de obra indígena pelos povoados de então. Com relação a repartição de mão de obra entre os moradores,

[...] passava a ser feita em duas partes iguais: 'uma delas se conserve sempre nas suas respectivas povoações, assim para a defesa do Estado, como para todas as diligências do seu real serviço, e outra parte para se repartir pelos moradores, não só para equipação de canoas, que vão extrair as drogas do sertão, mas para os ajudar na plantação de tabaco, cana de açúcar, algodão e todos gêneros, que podem enriquecer o Estado, e aumentar o comércio.

Os índios só eram entregues aos moradores mediante Portaria assinada pelo governador. A idade dos índios para o trabalho ia dos 13 aos 60 anos. Quantos aos salários desses trabalhadores, era de responsabilidade dos diretores, que deveriam receber de todos, dividido em três partes, sendo que apenas uma delas devia ser entregue aos índios, deixando outras duas em forma de depósito, pois em caso de fuga ou deserção dos índios, seriam devolvidas ao morador contratante. ${ }^{16}$

Desta forma se estabeleciam o contato e as atribuições do uso de mão de obra indígena na Amazônia Portuguesa, exatamente no período em que o Marquês de Pombal assumia a chefia do Estado. Para Patrícia Sampaio, a legislação colonial propunha transformar os “gentios" em vassalos do rei de Portugal, à medida em que o controle sobre os índios estava como uma das prioridades do Governo Pombalino, para a historiadora, a vassalagem dos índios dar-se-á com o Diretório de 1757 e com a Carta Régia de 1789. ${ }^{17}$

Com a discussão acima, pretendo evidencia que entre as medidas tomadas acerca do trabalho indígena na Colônia, e a posteriori na Província, houve uma série de permanências latentes no trato com os indígenas. As formas de captura dos índios mudaram, eles agora eram trazidos mais pela coerção que pela força física, se na Colônia seu principal uso era na coleta

\footnotetext{
${ }^{14}$ TEIXEIRA, Carlos Corrêa. Visões da Natureza: Seringueiros e colonos em Rondônia. São Paulo: EDUC, 1999.p.116.

${ }^{15}$ Conhecido também como Diretório dos Índios, Diretório de Pombal, o nome verdadeiro desse documento é Directorio que se deve observar nas povoações dos índios do Pará e Maranhão em quanto Sua Magestade não mandar o contrario. (Grafia da Época)

${ }^{16}$ SANTOS, Francisco Jorge dos. Além da Conquista: Guerras e Rebelióes na Amazônia Pombalina. $2^{\mathrm{a}}$ ed. Manaus: Editora da Universidade do Amazonas, 2002. p.p.51, 52.

${ }^{17}$ A Carta Régia estabelece um novo momento de organização trabalhista na Colônia. O índio passa a ampliar seu campo de atuação enquanto trabalhador - vassalo. A este passou a ser permitido ingresso na carreira militar, ser comerciante dentre outras ocupações. Os índios aldeados passaram a ser "livres" e podiam ser contratados por particulares. Entre o Diretório e a Carta Régia há de fato muitas diferenças com relação ao trato da mão de obra, jamais sobre a liberdade dos índios. Este sempre foi considerado como "inferior não civilizado, bárbaro ou gentio." Ler mais em: SAMPAIO, Patrícia Melo. "Desigualdades Étnicas e Legislação Colonial Pará, C. 1789 C.1820." In: Amazônia em Cadernos. Manaus: Editora da Universidade do Amazonas, nº 06, 2000. p. 271 - 316.
} 
extrativista das drogas do sertão, agora eram mais utilizados em trabalhos braçais na capital para erguer os prédios que reconfiguraram a paisagem do espaço urbano, eram trabalhadores da cidade na qual deveriam se encontrar com a civilização exercendo os pesados trabalhos aos quais eram empregados.

\section{Os Presidentes da Província e os Índios}

Na cidade de Manáos, a mão de obra indígena foi muito utilizada. Conforme os relatórios dos presidentes de Província, foram levas de indígenas trazidos da hinterlândia da Amazônia para exercer os mais diferentes ofícios braçais na capital da borracha. Basicamente grande parte dos trabalhadores dessa mão de obra, era convocada pelas ações do Corpo de Trabalhadores que fora criado pela Lei $\mathrm{n}^{\circ} 2$ de 25 de abril de 1838, ainda no primeiro quartel do oitocentos no então Estado do Grão-Pará e Maranhão ao qual o Amazonas estava subordinado. A composição desses trabalhadores era maiormente índios e tapuios. Segundo alguns historiadores, o Corpo de Trabalhadores fora modificado por leis em 1840 e 1841 . De fato, acreditamos que

[...] Estes homens recrutados pelo Corpo de Trabalhadores eram utilizados para os serviços braçais. Este instrumento de arregimentação de mão de obra não funcionava a contento dos administradores que tinham consciência de que em algumas situações, estes operários, que já eram poucos e despreparados para o serviço, eram, em algumas situações, utilizados para satisfazer ambições e ganhos ilícitos. Esta certeza tornou-se a justificativa, em 1852, para que o vice-presidente Corrêa Miranda solicitasse a dissolução do mesmo e propusesse a criação de um Corpo de Pedestre, que diferente do Corpo de Trabalhadores onde todos tinham que também estar aptos para a Guarda Nacional, alistaria todos os homens disponíveis, porém sua resolução não foi acatada. ${ }^{18}$

Toda a sociedade se empenhava em utilizar e tirar usufruto dos serviços dos indígenas, uma vez que no discurso, eles "eram a grande horda que somente ajudaria a Província a crescer se trabalhasse", nesse discurso, se criava a ideia que o uso do índio em trabalho era positivo haja a vista com o trabalho ele seria apto a civilização, o trabalho lhe daria aptidão para o convívio social.

Segundo a historiadora Patrícia Sampaio,

O uso continuado, reiterado e preferencial da força de trabalho indígena na Amazônia não pode ser esgotado apenas em uma limitação de recursos monetários que este fator represente um peso decisivo. É preciso que consideremos os outros fatores que compõem o sistema econômico da

\footnotetext{
${ }^{18}$ RABÊLO, Ana Paula de Souza. Do Templo de Taipa ao Templo de Pedra: A construção da Igreja Matriz de Manaus (1858 - 1878). Manaus: Dissertação de Mestrado em História, Universidade Federal do Amazonas UFAM, 2008. p. 129.
} 
região, afim de visualizar claramente o significado do fator força de trabalho, nesse contexto. ${ }^{19}$

Foram utilizadas diversas maneiras pelo poder público para atrair os índios a virem trabalhar nas obras públicas de Manáos, inclusive, se aceitava que os mesmos trouxessem suas esposas para a cidade. Numa circular emitida aos diretores de índios, em 1858, lemos,

Circular- Aos Diretores parciais de índios. Mande vossa mercê apresentarme nesta Capital com toda a brevidade dez índios de sua Diretoria para o serviço das obras púbicas; os quais deverão ser substituídos por igual número ao cabo de dois meses; permitindo-lhes vossa mercê trazerem consigo suas mulheres, se eles quiserem. Paia que esta substituição se faça com a precisa regularidade, cumpre que vossa mercê designe com a necessária antecedência aqueles que deverão vir substituir em tempo oportuno. ${ }^{20}$

Percebemos que o governo não cessava de propor ao índio a vinda a cidade para integrar a mão de obra, trazer suas mulheres a cidade, pensemos que seria uma forma de os mesmos serem incorporados por mais tempo ao serviço uma vez que segundo seus contratos de trabalhos, eles ficariam na cidade por um período de no máximo dois meses, mas havia uma grande necessidade de permanecerem por tempo mais extenso uma vez que estavam surgindo diferente obras nas quase seus braços seriam utilizados.

Também observamos nas entrelinhas como se dava o contrato de trabalho e a provável renovação dos trabalhadores. Ao cabo de dois meses trabalhados, os indígenas eram substituídos por outros onde caberia ao máximo o trabalho dos diretores, comandantes e oficiais para o recrutamento dos índios para as obras da cidade não entrarem em estagnação. Lendo a documentação percebemos que havia um empenho para de fato se abrigarem o máximo de índios nos trabalhos, em tempo regular.

Em 1858, num oficio encaminhado para a Diretoria das Obras Públicas, há a informação que para as obras da Igreja Matriz chegaram a Manaus quatorze índios vindos da região do Taupeassu, nisso,

Ao mesmo [diretor interino das obras públicas]. Pelo seu ofício de ontem sob o número 289 fiquei inteirado de se haverem apresentado mais três trabalhadores do Tauapeassu de nomes Joaquim Pedro, Victorino Antônio Gomes, e Sebastião Gonçalves; aos quais se acha, empregados na obra da nova Matriz... ${ }^{21}$

\footnotetext{
${ }^{19}$ SAMPAIO, Patrícia Maria Melo. Os Fios de Ariadne: Fortunas e Hierarquias Sociais na Amazônia, Século XIX. $2^{\text {a }}$ Ed. São Paulo: Editora Livraria da Física, 2014.p. 79.

${ }^{20}$ JORNAL Estrella do Amazonas, $\mathrm{n}^{\circ}$ 280, de 27 de março de 1858. Expediente de 23 de março de 1858. Acervo da Biblioteca Nacional. Disponível em: http://bndigital.bn.br/acervo-digital/estrella-amazonas/213420. Acesso em 12/01/2016.

${ }^{21}$ JORNAL Estrella do Amazonas, $\mathrm{n}^{\circ} 346$ de 25 de dezembro de 1858, expediente de 20 de agosto de 1858 . Apud: RABÊLO, Ana Paula de Souza. Op. Cit., p.51. A autora informa que se chega ao número de 14 trabalhadores a partir do pedido de rações dos trabalhadores empregados na obra da Igreja Matriz.
} 
Com a citação acima vemos que o empenho em trazer trabalhadores indígenas estava de fato em andamento. A cidade era um turbilhão. Era um grande canteiro de obras e obras de uma magnitude nunca vista antes, como a citada obra da Igreja Matriz de Nossa Senhora da Conceição. Porém, nem tudo era tão fácil assim, pois os índios se negavam a vir trabalhar, não aceitavam tudo tão rapidamente, e, resistiam aos pressupostos.

Portaria-O Presidente da Província determina aos Diretores dos índios, Comandantes e Oficiais de Trabalhadores, e Inspetores de Quarteirão e aos oficiais da Guarda Nacional que prestem toda a coadjuvação que lhe for requerida pelo Capitão Jozé Cazemiro Ferreira do Prado para o desempenho da comissão de que vai encarregada de trazer índios e Trabalhadores para as obras Públicas.

Dita - O Presidente da Província autoriza ao Capital Jozé Cazemiro Ferreira do Prado a afiançar garantir aos índios, - e Trabalhadores, que vai encarregado de trazer para o serviço das obras Públicas, o salário pe [sic. ] 320 réis em dinheiro, e igual quantia em alimentos, e á serem os mesmos dispensados do serviço, e voltarem para suas casas ao cabo de dois meses. ${ }^{22}$

Pela portaria acima transcrita, o presidente empenha-se em conseguir atrair e recrutar mão de obra indígena a todo custo. Mas, se havia uma grande empresa, uma grande preparação e uma convocação da proporção da acima citada para auxiliar no recrutamento desses homens, podemos observar que de fato existia uma resistência, uma luta, um "não querer" por parte dos indígenas. Percebemos nesse trecho também as benesses, os direitos aos que os indígenas receberiam possivelmente. Dentre os quais, o redator cita que o salário que os mesmos receberiam seria a importância de 320 réis, salário ínfimo pois as condições de trabalho eram perigosas e hostis, e bem como se manter com esse salário era muito difícil pois os preços eram elevadíssimos. Também receberiam 320 réis em alimentos, a comida que era denominada "ração". E o terceiro ponto a temporalidade de serviço que era de dois meses, sendo substituídos por outros posteriormente.

Segundo o presidente da província José Furtado, no período de setembro de 1858 e abril de 1859, as obras públicas contavam no seu corpo de trabalhadores com vinte e sete índios serventes e quatro africanos livres. Ao todo serviram a esta repartição cento e cinquenta e cinco indígenas dentre os quais vinte e um abandonaram, desertaram o serviço, quatro foram encaminhados as obras da Câmara Municipal, vinte e dois foram cedidos a serviços de particulares e oitenta e quatro receberam a dispensa. ${ }^{23} \mathrm{~A}$ lista a seguir apresenta-nos o pessoal empregado nas obras, sendo a maioria de indígenas.

\footnotetext{
22 JORNAL Estrella do Amazonas, no 389, de junho de 1859. Expediente de 03 de janeiro de 1859. Acervo da Biblioteca Nacional. Disponível em: http://bndigital.bn.br/acervo-digital/estrella-amazonas/213420. Acesso em 13/01/2016.

${ }^{23}$ RELATÓRIO que a Assembleia Legislativa Provincial do Amazonas apresentou na Abertura da Sessão Ordinária no dia 03 de maio de 1859. Francisco José Furtado, Presidente da mesma Província. Manáos:
} 
Figura 01: Lista de trabalhadores nas obras públicas de Manáos, 1859

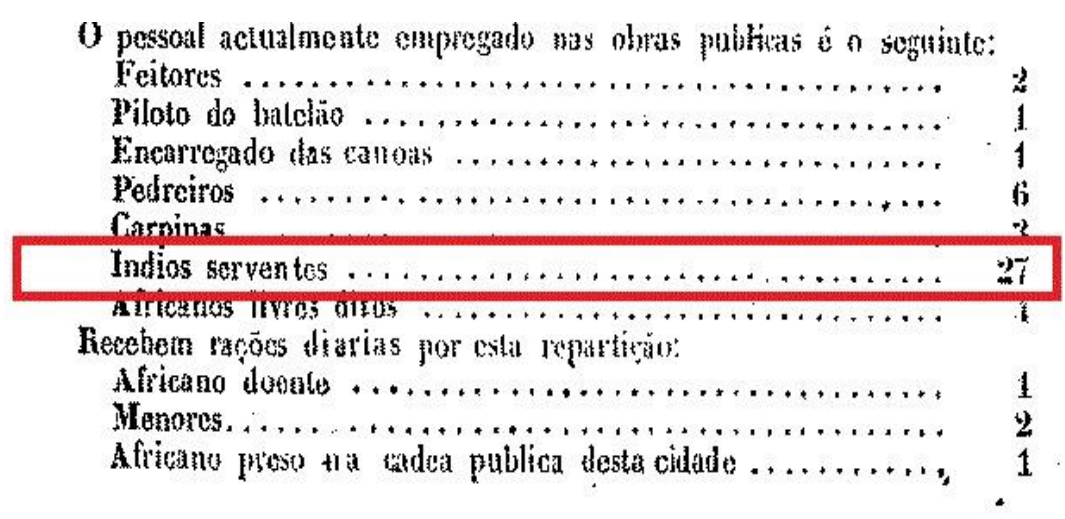

Fonte: Anexo 04 do Relatório do Presidente Provincial Francisco Furtado.

Explicitando a fala do presidente, lemos que os indígenas estavam em número considerável no cotidiano da cidade, e estavam inclusive adentrando as esferas da vida privada. Somente o governo tinha o poder de fazer remoções e capturas bem como trazer índios a cidade para serem trabalhadores, mas esse mesmo governo podia cedê-los a particulares para estes usarem de seus serviços. Havia assim, uma ampla utilização do índio na cidade. A estes particulares, além dos serviços braçais estes exerciam funções de lavadeiras, cozinheiras, aias, capatazes, roceiros, e até mesmo jardineiros e serviços de manutenção de casas. Assim, a mão de obra indígena era muito presente na cidade de Manaus.

No mesmo relatório, quando o presidente aborda o tema da Indústria, nos informa que a escravatura na Província é quase nula, e que "os nossos lavradores não confiam senão no trabalho escravo". Os lavradores acreditam que o índio livre não serve. O presidente cita a atuação de um senhor de nome Inglez Roberto que se encontrava fazendo trabalhos com índios, e índios Mura. Para o Presidente, o índio devia ser tratado como homem livre, seus empregadores deviam pagar corretamente seus salários, e não deviam exigir trabalhos além "das forças e aptidão de homens selvagens, ou semibárbaros" que não faltará braços para os trabalhos agrícolas. Tudo na agricultura, na navegação, na pesca, na extração de produtos naturais era feito pelos índios. ${ }^{24}$

Com essa discussão,

Fica evidente aqui que, apesar da necessidade sempre presente de mão de obra, as formas de recrutamento não correspondiam na proporção e eficácia desejada pelos administradores provinciais. As informações referentes ao funcionamento dos Corpos são incompletas e superficiais. Na sua maior parte, os Relatórios de Presidente de Província limitam-se a informar a

Typografia de Francisco José da Silva Ramos, 1859. Anexo 04. Acervo do Instituto Geográfico e Histórico do Amazonas - IGHA.

${ }^{24}$ Idem, p. 239

CANOA DO TEMPO - Revista do Prog. Pós-Graduação em História, Manaus, V. 9 - n1ㄴ dez 2017. 
existência de companhias em determinadas localidades, por vezes informam o nome do responsável pela sua manutenção e, em outros momentos, limitam-se a tecer comentários sobre a ineficiência de sua atuação sem fornecer maiores detalhes. ${ }^{25}$

De acordo com Carlos Moraes Camisão, diretor interino da Repartição de Obras Públicas em 1859, mesmo com a vinda destes indígenas, a cidade ainda carecia de operários, de bons operários. O referido diretor assim expressa seu posicionamento com relação a atuação dos índios nas obras da cidade, onde mesmo

[...] com abono da verdade deve dizer que numa máxima parte, conduzem-se bem, não faltam seu serviço, e são obedientes. Outro tanto, porém não posso dizer dos africanos livres, que são pela maior parte rixosos, vadios e dados ao vício da embriaguez. ${ }^{26}$

Nesta informação vemos apesar dos juízos de valor, uma descrição daquilo ocorria, ou melhor estava acontecendo no mundo do trabalho da cidade. Com a fala diretor fica evidente que os indígenas estavam concordando com as atribuições dos trabalhos e os exercendo com certo comprometimento, haja vista estavam agindo assim pois o governo estava atuando com o intuito de "melhorar", de amansar o índio e fazê-lo permanecer no serviço, reitero que muitas medidas foram realizadas pelos presidentes de província com a intenção de os índios por aqui ficarem dentre elas a já citada vinda de suas esposas a cidade. Com relação aos negros, continuavam com suas diversões e bebedeiras, fato que encaramos como resistência políticas ao que lhe estava sendo imposto. Mas os índios mesmo sendo mais "domesticados" permaneciam com fugas e é claro com ampla luta por não se adequarem as situações hostis que eram submetidos.

Havia uma espécie de disputa política ou oposição com relação aos funcionários e as hierarquias administrativas da Província. Uma destas era a dos Presidentes de Província que divergiam de muitas das atitudes dos Diretores Parciais de Índios, uma vez que estes percebiam muitas espoliações e usos indevidos da mão de obra indígena, concordamos, porém, que,

Apesar da oposição sistemática dos administradores provinciais à manutenção das Diretorias Parciais, elas cumpriam (ainda que precariamente) seu papel de manter constante o fluxo de mão de obra para a Capital, em especial para atender às obras públicas. É verdade que, em alguns momentos, a situação agudizou-se tendo sido necessária a

\footnotetext{
${ }^{25}$ SAMPAIO. 2014, Op. Cit. p. 80. De fato, com a leitura dessa documentação pouco colhemos em detalhes do desenvolvimento e da composição étnica dessa mão de obra, mas transpondo documentação, percebemos essa presença, no nosso caso, a participação indígena nessa mão de obra.

${ }^{26}$ RELATÓRIO que a Assembleia Legislativa Provincial do Amazonas apresentou na Abertura da Sessão Ordinária em o dia 3 de maio de 1859 Francisco José Furtado, presidente da mesma Província, Manáos, Typ. de Francisco José da Silva Ramos, 1859. Anexo 04. Acervo do IGHA.
} 
intervenção direta do Governo Provincial para garantir um minimum de mão de obra na cidade. ${ }^{27}$

De fato, como vimos até aqui, muitos indígenas foram trazidos para atuarem nas obras da cidade como na já citada da Igreja Matriz de Nossa Senhora da Conceição, bem como nas do Palacete Provincial, da Prefeitura Municipal, do Tesouro Público, do Liceu dentre outras. Todo esse sistema de trabalho, na qual os índios eram enviados a Manaus gerou características peculiares no regime de trabalho como afirmam estudiosos do trabalho na Amazônia. ${ }^{28}$ Todo esse sistema de luta, resistência e reinvenção estavam presentes na cidade e especialmente nas classes trabalhadoras, uma vez que:

$\mathrm{Na}$ Manaus que cresce e moderniza-se, forjam-se novos sujeitos sociais, os trabalhadores urbanos, distribuídos por um mercado de trabalho extremamente concorrido. Sobreviver na cidade, trabalhando, habitando ou divertindo-se, significava vivenciar experiências de dominação e resistência num aprendizado continuo [...]

Nesse mercado de trabalho urbano, que se constitui no início do período republicano, além da sobrevivência de formas de trabalho compulsório, observa-se que o assalariamento, pautado na monetarização das relações de trabalho, ainda não se apresentava como prática majoritária e regular de tais relações de trabalho. ${ }^{29}$

A historiadora Francisca Deusa Costa, ao nos mostrar esse universo ao qual os trabalhadores de Manaus estavam inseridos, enfatiza o ethos, a cultura que se formara nesse âmbito destacando os trabalhadores como partícipes e constituintes de uma cultura trabalhadora onde estes servidores antes de qualquer coisa lutavam, resistiam ao que estavam agregados. Com os apontamentos de sua pesquisa, percebemos a resistência como constitutiva do social e do urbano, pois os trabalhadores da cidade exerciam suas práticas nesse meio, mesmo que diversas vezes, impedidas pelas proibições contidas nos Códigos de Posturas, faziam com, ressignificaram esse cotidiano.

Nesse sentido, esses trabalhadores eram disciplinados para exercerem suas atividades uma vez que no século XIX, disciplina era valor recorrente e exercer ofícios urbanos poderiam causar perturbações que contradiziam ao poder disciplinar. É comum na documentação lermos itens que apontam para disciplinarização do espaço público, pois no Oitocentos, a cidade como palco dos acontecimentos deveria ser antes de tudo disciplinada.

\footnotetext{
${ }^{27}$ SAMPAIO. 2014, Op. Cit. p. 82.

${ }^{28}$ Incluem-se nesse meio os trabalhos de Maria Luíza Ugarte, Luís Balkar de Sá Peixoto, Francisca Deusa Sena, Alba Barbosa, César de Queirós dentre outros. Atualmente muitas pesquisas vêm sendo produzidas nesse âmbito pois é crescente a atuação historiográfica do Grupo de Trabalho "Mundo do Trabalho sessão Amazonas", coordenado pelo professor Davi Avelino, onde regularmente estudantes de Stricto Sensu, de Graduação e interessados reúnem-se e discutem sobre as nuances do Trabalho no Amazonas.

${ }^{29}$ COSTA, Deusa. Quando viver ameaça à Ordem Urbana: Trabalhadores Urbanos em Manaus (1890/1915). Manaus: Editora Valer e FAPEAM, 2014. p.p. 42-43.
} 
O trabalho da historiadora Maria Luíza Ugarte, aponta para essa esfera destacando os sujeitos como conscientes e organizados atuante no meio capitalista excessivo que estavam imbricados, nisso a autora salienta que

[...] esse capital chegou a Amazônia atrelado a práticas de racionalização do trabalho cuja exemplificação mais cristalina talvez estivesse na mudança radical de alguns símbolos que tinham por finalidade disciplinar o uso do tempo, sobretudo o tempo do trabalho. Outrora, os sinos eram os referenciais nos quais a população percebia a chegada dos momentos específicos do rezar, trabalhar, comer, descansar e dormir. Abrindo-se ao mundo da racionalidade capitalista, Manaus precisou domar o poder normatizador do tempo, até então localizado na igreja ou na natureza. O progresso já tinha erguido outros ícones, sendo o trabalho o mais valorizado dentre todos. Em Manaus, como nas diversas partes do globo, esse era, em geral, anunciado pelo soara de apitos das fábricas, tidos como verdadeiros arautos da modernidade. ${ }^{30}$

O governo pregava bons tratos e boa relação de trabalho com os índios, porém, Edinea Mascarenhas, nos diz que aí se tem uma grande ambiguidade, pois esse discurso pode ser grande falácia, considerando que,

Um outro aspecto difícil de ser entendido, por parte das autoridades e patrões, com relação à postura do índio como trabalhador, é que, se eram bem tratados, se recebiam seus salários pontualmente, sendo dispensados no final de três meses, podendo então voltar para suas aldeias, porque tinham tão má vontade na atividade que executavam, não admitindo, inclusive, nenhuma admoestação. ${ }^{31}$

Com esta citação, visualizamos como era ditado as ocupações aos indígenas, porém este discurso, nem sempre acontecia assim. Acredito que se o indígena abandonava seu trabalho primeiramente é porque não estavam cumprindo com as promessas; segundo, as relações de trabalho e as condições eram desfavoráveis; terceiro e principal, não era da sua cultura, o trabalho cronometrado e acelerado, típico do meio urbano e capitalista.

De fato, por fonte do período verificamos que eram poucos os "senhores" que de fato cumpriam com o estabelecido por lei de que os indígenas deviam permanecer por apenas três meses. Há fontes/denúncias contra essa situação citada inclusive em relatórios dos presidentes da província. Quanto as condições de trabalho, nesse período como trabalhadores urbanos, os índios passaram a se enquadrar no grande rol daqueles que ameaçavam a almejada ordem urbana que a belle époque impunha. Deusa Costa, destacou isso com autoridade. Em sua pesquisa, a autora apresenta que o assalariamento da mão de obra de Manáos, pelo número de greves e por diversas reclamações presentes na imprensa cotidiana seja operária ou não, fica

\footnotetext{
${ }^{30}$ UGARTE, Maria Luíza. A Cidade Sobre os Ombros: Trabalho e Conflito no Porto de Manaus (1899-1925). Manaus: Editora da Universidade Federal do Amazonas EDUA, 2003. p.118.

${ }^{31}$ DIAS, 2007, op. cit.
} 
evidente que o compromisso do "patronato local" não era cumprido. ${ }^{32}$ O que nos leva a premissa que eram condições desfavoráveis ao índio, que sabendo ser e se portar no ambiente de trabalho, fugia com frequência do trabalho que estava inserido.

As fugas, comuns entre os índios trabalhadores que foram trazidos a Manáos, era justificável por diversos fatores. Segundo os relatórios dos Presidentes da Província o salário era somado em 1. \$380 réis, que recebiam quando dispensados das obras, ao término do tempo proposto, que reitero eram dois meses como substituição. Depois de um tempo, esses índios passaram a serem providos com alimentação e roupas também. Porém, as fugas eram permanentes.

Em sua fala dirigida a Assembleia Legislativa Provincial do Amazonas, no dia $1^{\circ}$ de outubro de 1853, assim o Presidente Herculano Ferreira pena se referia as fugas e demonstrava que, de fato os índios "quando desejam fugir não há interesse que os detenha, mas esse desejo também nasce muitas vezes da injustiça e má fé de certos patões, que os maltratam, ou não lhe pagam os pequenos salários do estilo. "33

Para o Presidente, o índio é altivo, e se foge é porque era um todo usurpado pelos seus empregadores que o fraudavam em diversos âmbitos, especialmente no tocante a seus honorários, caracterizando assim, repiso, que seu trabalho era um trabalho compulsório. Prosseguindo seu discurso, o presidente esclarece as causas dessas ações estarem ocorrendo. Nas palavras do presidente:

\begin{abstract}
A explicação que tenho ouvido de alguns destes casos não deixa de ser curiosa: quando o índio alega que fugiu porque já tinha trabalhado muitas semanas ou meses sem receber coisa alguma, responde o patrão - que não lhe pagava porque ele fugiria no mesmo momento em que recebesse o dinheiro, [sic. ] Creio que a pessoa menos afeiçoada ao pobre indígena não deixará de reconhecer que em tais circunstâncias dá ele a maior prova de resignação e de generosidade tomando a fuga por único recurso. ${ }^{34}$
\end{abstract}

Fica expresso pelo posicionamento do Presidente duas questões bastante singulares nesse mundo do trabalho: a primeira diz respeito a organização e astucia dos indígenas a ponto de se rebelarem por não terem recebido aquilo que ficara acordado entre o governo e seu patrão, nesse ponto percebemos que as relações de trabalho na cidade eram em um todo complexas e os índios sendo tutelados, não podiam expressar sozinhos seus direitos, o Presidente fez sua parte e os reivindicou, mas pela análise documental percebemos que

\footnotetext{
${ }^{32}$ Ler mais em: COSTA, Deusa. Op. Cit. 61 et. seq.

${ }^{33}$ FALA dirigida a Assembleia Legislativa Provincial do Amazonas, no dia 1.o de outubro de 1853, em que se abriu a sua 2.a sessão ordinária, pelo Presidente da Província, o conselheiro Herculano Ferreira Penna. Manáos, Amazonas: Typ. de M.S. Ramos, 1853. p. 54 Acervo IGHA.

${ }^{34}$ Idem, p.p. 54, 55. Grifos meus.
} 
mesmo assim nada mudara para os indígenas, e estes, utilizavam da única estratégia disponível para resistir: a fuga.

O segundo ponto a se destacar nessa fala, evidencia o caráter discursivo que circulava na cidade. Ao procurar "ouvir" o índio, o Presidente expressa que o índio sabia de seus direitos, tinha compreensão daquilo que era seu. Esse ponto vem nos apresentar que a ideia de que o índio era tolo ou manipulável era um discurso pois como teorizou Michael Foucault,

[...] a produção do discurso é ao mesmo tempo controlada, selecionada, organizada e redistribuída por certo número de procedimentos que têm por função conjurar seus poderes e perigos, dominar seu acontecimento aleatório, esquivar sua pesada e temível materialidade. ${ }^{35}$

Acreditamos assim que ao se cristalizar o discurso de que os índios eram "tolos e aceitavam ser espoliados", a sociedade se beneficiava e abusava por ver os indígenas como "selvagens e sem vontade própria," fato que não era verossímil pois o índio luta e se defende utilizando estratégias de sobrevivências.

O índio resistia ao trabalho, pois mantinha uma relação peculiar com a natureza. Essa idiossincrasia fazia o índio ver e extrair o essencial da natureza, plantava e praticava o cultivo da terra para a sua sobrevivência, sem visar lucros ou relações comerciais em grande escala. Isso era o modo de vida dos índios. Ao serem trabalhadores, os índios agora passaram a formar uma classe que na Província era tão ínfima quanto aos não brancos. Talvez, por ser formada demasiadamente por índios, a classe trabalhadora de Manaus era tão malvista, e foi cada vez mais marginalizada, pois além de índios agora eram trabalhadores, "sujos, imundos, pobres, indisciplinados."

Disciplina tornou-se a palavra e a prática da vez, pois a cidade disciplinar era aquela que devia ser limpa, e sua população também. Porém para os índios, o trabalho não simbolizava algo engrandecedor, pois,

Na verdade, não se trata de falta de ambição, preguiça ou desobediência aos patrões. O fato é que as manifestações culturais são diferentes e a forma de relacionamento do produtor índio com a natureza era outro, pois o trabalho indígena ainda se encontrava articulado com o valor de uso, e as modernas relações materiais de sobrevivência ainda não os havia atingido. A racionalidade econômica do sistema moderno de produção ainda não os dominava. A produção das comunidades locais ainda era orientada pelas necessidades e não pelo lucro. ${ }^{36}$

Vemos que o índio, ainda matinha seus costumes é hábitos vivos, mesmo que estivessem agindo na lógica dominante. $\mathrm{O}$ não ao salário, o não ao trabalho, era uma resistência que, dava ao índio um rótulo que se cristalizou de preguiçoso, desidioso.

\footnotetext{
${ }^{35}$ FOUCAUT, Michel. A Ordem do Discurso. Aula inaugural no Collège de France, pronunciada em 02 de dezembro de 1970. Trad. de Laura Fraga de Almeida Sampaio. São Paulo: edições Loyola, 1996. p.p. $08,09$.

${ }^{36}$ DIAS, 2007, Loc. Cit.
} 
Os indígenas, ao fugirem do trabalho estavam evitando prosseguir com seu modo peculiar de vida e, dizer não ao processo de branqueamento pelo qual passou a cidade. Uma das tentativas de suplantar as características indígenas foi segundo alguns autores a crescente demografia do fim do século XIX, pois,

O repentino crescimento populacional ocorrido em Manaus, nas três últimas décadas do século XIX, em virtude do fluxo migratório, é mais um dado relevante para a construção de hipótese de que, na última década daquele século, vários fatores participaram do processo de refundação dessa cidade. Além de provocar a ampliação dos limites urbanos, foi promovido um processo de branqueamento étnico e cultural da população local. A diversidade de manifestações criava uma predisposição para as inovações e para a formação de uma sociedade menos tradicional e mais cosmopolita. ${ }^{37}$

Ou seja, era preciso impor ao índio o trabalho, uma vez que a elite queria mudar a face da sociedade manauara, tradicionalmente indígena, para uma cidade, estrangeira, com moldes europeus, no qual o trabalho engrandecia o homem e sua cidade.

Samuel Benchimol, nos diz que mesmo como boom da borracha, caboclos e índios, em sua maioria permaneciam exercendo seus ofícios de "agricultores, extratores, pescadores e mateiros encerrados e estratificados dentro de um sistema social que possuía alguns aspectos de casta," nisso:

Muitos poucos, filhos nativos tiveram sucesso no estabelecimento de seus próprios negócios. O seu "status" social e econômico era baixo e sua principal função na comunidade se limitava a funções de menor importância, como empregados domésticos e de escritórios e funcionários públicos. A mulher nativa conseguia emprego como cozinheira e serviçal doméstica nas residências dos brancos ou em algum bar ou restaurante, quando não eram prostituídas, como frequentemente ocorreria. ${ }^{38}$

Mesmo trabalhando, os índios pouco ascendiam socialmente, à medida que ser índio naquele momento, para muitos era não ser civilizado, era ser marginalizado de diversas formas. Uma forma de ascensão era por meio do serviço militar. O regulamento do serviço “de catechese e civilisação” de índios, do Decreto № 248, de 28 de maio de 1898, rege:

$\S$ 65. Alistar os índios para guardar policiais do burgo e adestrá-los em exercícios militares.

§ 66. Animar com dádivas o índio que mais gosto e zelo mostrar pelo serviço e ter todo o cuidado em não desgastá-lo por excesso de trabalho. ${ }^{39}$

\footnotetext{
${ }^{37}$ MESQUITA, Otoni Moreira. La Belle Vitrine: Manaus entre dois tempos (1890-1900). Manaus: Editora da Universidade Federal do Amazonas EDUA, 2009.

p. 188 - grifos do autor -.

${ }^{38}$ BENCHIMOL, Samuel. Amazônia: um pouco antes e além depois. Manaus: Editora Umberto Calderaro, 1977. p. 81. Grifo meu.

${ }^{39}$ Decreto $\mathrm{N}^{\mathrm{o}} 248$ de 28 de maio de 1898 ...p. 19 - Acervo do IGHA
}

CANOA DO TEMPO - Revista do Prog. Pós-Graduação em História, Manaus, V. 9 - nำ1, dez 2017. 
De certo muitos índios foram integrados neste serviço. O inciso 66 é bem interessante. Ele permite agrados ao índio que participe ativamente, o índio bom, aquele que ajuda no desenvolvimento. Este índio enquadrou-se no universo do branco, mas permaneceu sendo visto como inferior e criou-se um discurso em Manaus de que o índio jamais poderia ocupar o lugar que fora outrora de um branco.

Outro serviço no qual também houve certamente muita utilização de indígenas na cidade foi no serviço denominado Companhia ou Batalhão de Ligeiros, um serviço militarizado instituído no Pará em 1835 por uma lei Provincial, que foi modificado pelas leis de 24 de outubro de 1840 e de 12 de junho de 1841. Sua finalidade era enquadrar e chamar ao trabalho "todos os índios domesticados, mestiços, e pretos livres ou libertos que não se achassem em circunstâncias de serem alistados na Guarda Policial. "40 Segundo Mário Ypiranga,

A diferença que havia entre o corpo de trabalhadores e o de ligeiros, é que estes eram recrutados para qualquer serviço braçal, especialmente remeiros nas embarcações particulares, pois a Metrópole possuía suas guarnições, os "remeiros régios", muito bem pagos e fardados, além dos galés que trabalhavam somente pela comida e acorrentados nos pés, usando aquela roupa inconfundível, de riscas pretas. A hierarquia no trabalho braçal seria de cima para baixo, como segue: intendente das obras ou empreiteiros, feitor, mestre de obras, canteiros, sapadores, empalhadores, artistas pintores, carregadores, carapinas, serventes, aprendizes e cabouqueiros, estes escravos pretos. $[\ldots]^{41}$

Ao destacar o trabalho indígena na cidade de Manaus, pretendemos mostrar que eles estavam presentes por aqui, mesmo que em condições pregadas como "subordinados", mas eles aqui estavam. Pela documentação apresentada, visualizamos que o discurso pregava que os índios somente estavam aqui, pois eram trazidos, descidos ou de outra forma de recrutamento, vinham exercer a função de trabalhador, porém eles também exerciam sua cultura e suas práticas na cidade se tornaram cada vez mais visíveis uma vez que a cidade ainda era e muito de tez indígena.

Maria Regina Celestino, em sua tese de doutoramento sobre a identidade cultural nas aldeias do Rio de Janeiro disserta sobre a presença indígena na Colonização do Rio de Janeiro. Ao retratar a questão do trabalho indígena, esta autora afirma que do século XVI, ao XIX, as populações indígenas foram membras da força de trabalho na capitania do Rio de Janeiro. Essa integração variou ao longo do tempo, mas, fato é que a mão de obra indígena como em toda a América foi fundamental para o plano colonizador. É importante destacar que,

\footnotetext{
${ }^{40}$ MONTEIRO, Mário Ypiranga. Arquitetura: Tratado sobre o Prédio Amazonense. Manaus: sem editora, 2006. p.274.

${ }^{41}$ Idem, p. 275.
}

CANOA DO TEMPO - Revista do Prog. Pós-Graduação em História, Manaus, V. 9 - nô1, dez 2017. 
Os povos indígenas, no entanto [...], não estavam à disposição dos europeus e sua incorporação ao mercado de trabalho na capitania como aldeados ou como escravos - fez-se através da legislação e de muitas disputas cotidianas. O trabalho compulsório era obrigação dos índios aldeados, mas tinha limites estabelecidos pela lei e pela resistência dos índios, com forte apoio dos jesuítas até sua expulsão. [...] A inserção dos índios nas atividades produtivas da capitania passava também por seus próprios interesses e motivações. ${ }^{42}$

Com esta citação, verificamos que a resistência indígena passa por disputas e práticas que muitas vezes passaram despercebidas na escrita da história. Como já relatamos, em Manaus no período analisado, diversas resistências políticas ao que era imposto foram incorporadas, vivenciadas e postas em experiência no cotidiano citadino. No mundo do trabalho, como vimos também aconteciam as lutas, mesmo que silenciosas. A inserção de indígenas nas obras públicas ou particulares, brotavam de múltiplas motivações e interesses tais como: a necessidade de mão de obra, a ética e o ideal civilizatório, moral e cristão do mundo branco, a transformação social que a modernidade acarretava a população da cidade, dentre outras.

O quadro a seguir apresenta sistematicamente como se dava a contratação, a apropriação dos indígenas por parte do governo provincial, e como estes resistiam na lógica dominante. Como se dava a atuação de diferentes atores nesse e o cenário que se formou no mundo do trabalho na província, e especialmente em Manaus nesse período.

Quadro: Recrutamento, uso e condições do Trabalho Indígena em Manaus1850-1870

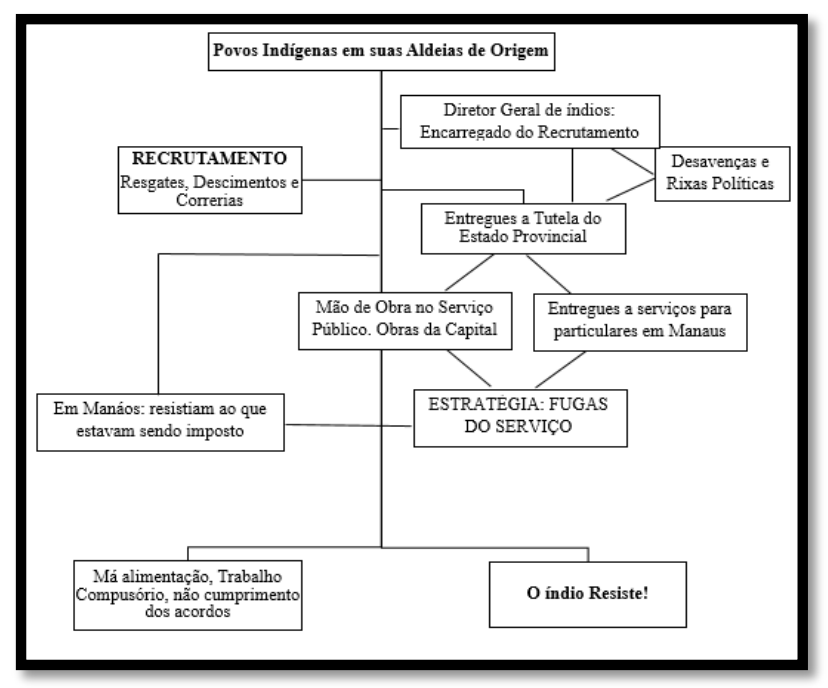

Elaborado pelo autor

\footnotetext{
${ }^{42}$ ALMEIDA, Maria Regina Celestino de. Metamorfoses Indigenas: Identidade e Cultura nas aldeias coloniais do Rio de Janeiro. Rio de Janeiro: Arquivo Nacional, 2003. p.188.
} 
Pela leitura do quadro acima, acreditamos que muito permaneceu da forma colonial de trato com os índios especialmente no aproveitamento de sua mão de obra no decorrer do Oitocentos em todo o território nacional. O quadro tem sua linha final em 1870, data na qual a documentação "esconde" o trabalho indígena em conformidade com a vinda dos trabalhadores do nordeste brasileiro que começam a chegar, porém, acreditamos que por muitos anos, a mão de obra indígena ainda foi utilizada na cidade, até mesmo em meados do século XX essa era uma presença marcante. Em Manaus, a legislação sofria até algumas alterações, porém, o trato e uso do trabalho indígena era oportunizado e utilizado em muitos momentos, afinal por aqui, eles eram os "únicos braços com que a Província podia contar", mas essa mesma província se via diante de muitos desafios pois estes indígenas não estavam a sua mercê, não eram tolos ou fracos ao ponto de aceitarem todos os pressupostos a que eram submetidos.

Assim o trabalho indígena era uma alternativa eficiente e racional, uma medida inteligente para uma economia precária que de repente alcançara um boom tendo pouco preparo por parte de seus administradores para conduzi-lo sem muitas estratégias. Vale destacar que os escravos negros estavam cada vez mais presentes nesse corpo de trabalho, mas o número maior ainda permanecia com os índios, afinal, a maior parte da população regional era de índios e caboclos.

\section{Os ofícios exercidos: imagens de trabalho}

Pela leitura das fontes aqui apresentadas, vemos que havia aquilo que o historiador John Manuel Monteiro chamou de "ideia de que que o índio é naturalmente resistente, ” - o índio é rebelde. Para este autor, esta ideia enfatiza uma visão da historiografia mais oficial do Brasil na qual o indígena tinha/tem uma tendência de "oposição obstinada". Queremos destacar que se o indígena resiste, se de fato ele luta não é por valentia ou por se mostrar superior aos pressupostos dos outros, porém acreditamos que a luta indígena, que a resistência parte de uma ação na qual

Para se repensar a resistência dos índios faz-se necessária uma reinterpretação abrangente dos processos históricos que envolviam essas populações. Mais do que isso, é preciso também reavaliar como os diferentes atores nativos criaram e construíram um espaço político pautado na rearticulação de identidades, contemplando evidentemente não apenas as formas pré-coloniais de viver e de proceder, como também e especialmente sua inserção - ou não - nas estruturas envolventes que passaram a cercear cada vez mais as suas margens de manobra. $[\ldots]^{43}$

\footnotetext{
${ }^{43}$ MONTEIRO, John Manuel. Armas e Armadilhas: História e Resistência dos Índios. In: NOVAES, Adauto. (Org.) A Outra Margem do Ocidente. São Paulo: Companhia das Letras, 1999. p.p. 241 -242.
} 
Nisso ao trabalharmos com a questão da utilização do braço indígena pretendemos discutir a presença deles na cidade de Manaus, mesmo que integrando uma classe que a sociedade, e a historiografia oficial tenderam a silenciar. Percebemos que de fato a partir dos anos 1879 há um "sumiço" com relação aos trabalhadores indígenas da documentação oficial, uma vez que a partir desse ano as levas de trabalhadores vindo do Nordeste Brasileiro tornouse ampla em função do crescimento dos trabalhos de extração da goma elástica. Porém, os índios ainda estavam por aqui.

Nas figuras seguintes, vemos a sociabilidade da cidade expressa na rua, local onde podemos observar havia uma grande concentração de trabalhadores exercendo seus ofícios na cidade da borracha.

Figura 02: Fachada da Catedral Nossa Senhora da Conceição - Matriz de Manáos

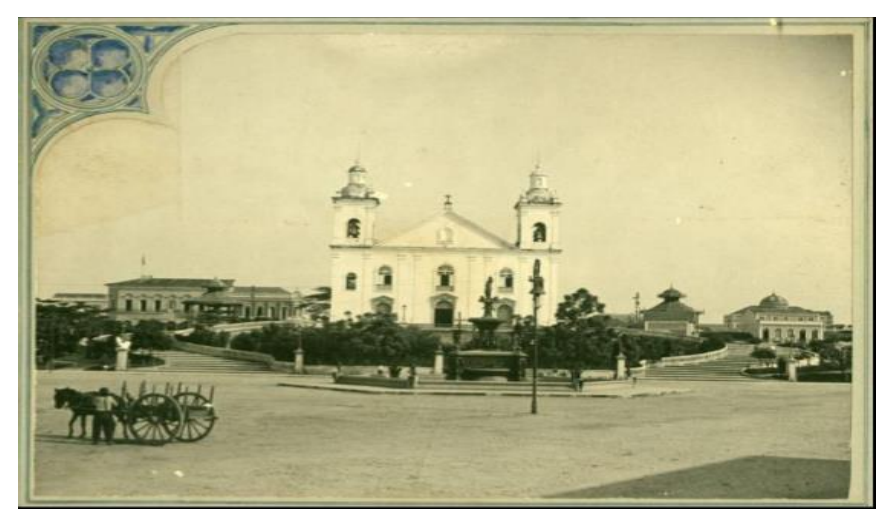

Fonte: Álbum do Amazonas 1901 -1902. Acervo Pessoal

Figura 03: Pubic Market - Manáos/ Mercado Público - Manaus

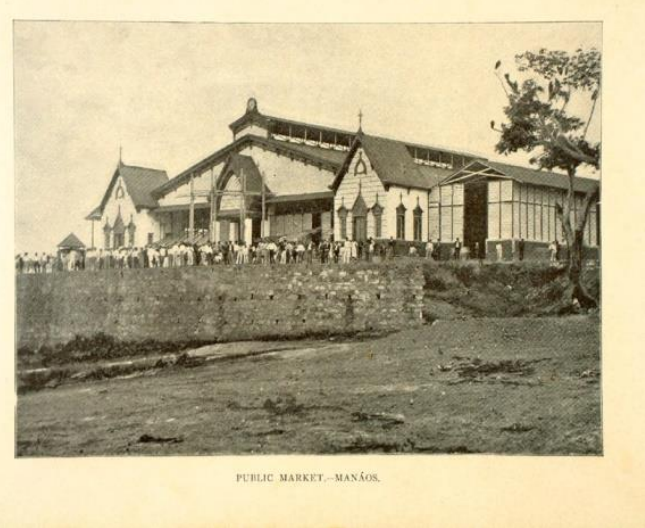

Fonte: Álbum Souvenir da Exposição Universal de Chicago.

"The City of Manaus and the Country of Rubber Tree", 1893. 
Figura 04: Rua Saldanha Marinho

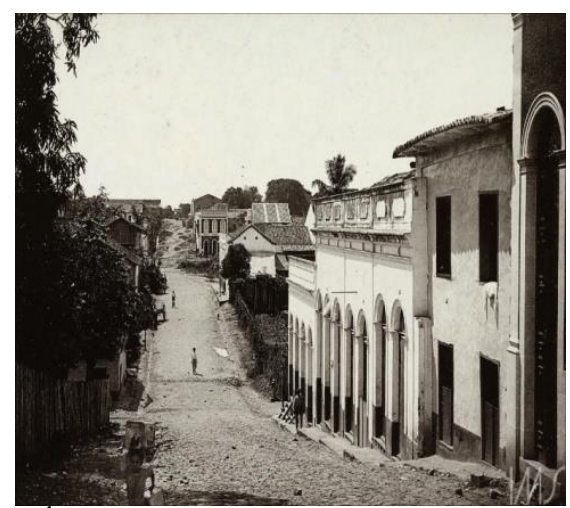

Fonte: Álbum do Amazonas 1901 -1902. Acervo Pessoal

Nas fotografias acima de três momentos da história de Manaus, visualizamos a cidade, seus prédios, e seus trabalhadores. A figura 02, vemos uma cena cotidiana de Manaus entre 1901-1902, a imagem retrata o entorno da Igreja Matriz de Nossa Senhora da Conceição. Vemos uma charrete, típico meio de transporte do período, e o condutor da mesma. Mais um exemplo de trabalho exercido na cidade da borracha. A figura 03, extraída do álbum souvenir da exposição de Chicago de 1893, mostra-nos o exterior do Mercado Público. Em frente há uma diversidade de pessoas em sua maioria homens e meninos, possivelmente os funcionários do próprio mercado e de outras repartições e, evidentemente, os operários que ali se encontravam.

A figura 04, apresenta-nos uma Rua de Manaus em 1890. O importante da referida fotografia, que queremos destacar como nosso ponto de fuga, são as pessoas que estão presentes nessa rua. Vislumbramos trabalhadores na cidade, fazendo serviços braçais, nas obras de pavimentação e possivelmente alargamento da via pública. Esses sujeitos certamente eram índios ou caboclos que eram providos para esses serviços.

Concluindo a análise iconográfica acreditamos que,

Uma fotografia é simultaneamente uma pseudopresença e um signo de ausência. As fotografias, especialmente de pessoas, de paisagens e cidades longínquas, de um passado irrecuperável, assim como uma lareira numa sala, são incitamentos ao devaneio. [...]

A questão torna-se mais complexa quando a fotografia é utilizada para estimular impulsos morais. O desejo não tem história - pelo menos é experimentado em cada momento como incontornável e imediato. É suscitado arquétipos e, nesse sentido, é abstrato. Mas os sentimentos morais estão embebidos na história, cujos personagens são concretos e cujas situações são sempre especificas. Assim, há regras quase opostas que são válidas na utilização da fotografia, quer para despertar o desejo, quer para despertar a consciência. As imagens que mobilizam a consciência estão 
sempre relacionadas com uma situação histórica determinada. Quanto mais gerais forem, menos hipóteses têm de ser eficazes. ${ }^{44}$

Embasando nossa leitura iconográfica nas ideias da autora acima citada, enfatizamos que a humanidade ainda permanece presa a "estatutos de verdade", ou seja, na lógica dominante da Manaus do século XIX, especificamente, na Belle Époque, não haviam indígenas na cidade em seu entorno. Porém, esta mesma lógica pregava que o indígena era a única força para os trabalhos braçais provinciais, especialmente na capital Manáos. Pelas fotografias acima, referenciamos um ponto de fuga ${ }^{45}$ que parte das pessoas presentes nelas, antes de verificarmos a paisagem ou o traçado urbano, ou ainda os edifícios presentes nelas.

$\mathrm{Na}$ figura 05, seguinte, diferente das demais vemos trabalhadores da borracha. Empregados na extração do caucho, esses homens certamente eram migrantes do Nordeste Brasileiro que para cá vieram iludidos pela falácia do enriquecimento fácil e rápido.

Figura 05: CAOUTCHOUC PROCESS NO. I The men set to work bleeding the base of the Castilloa

(Processo de Coleta do CauchoOs homens definidos para trabalhar a base de sangramento

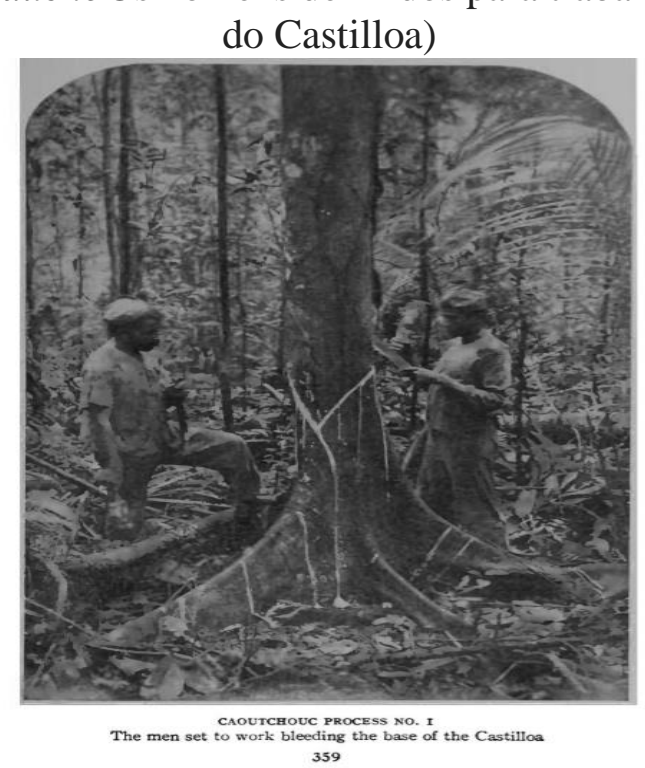

Fonte: Acervo da Biblioteca Brasiliana Guita e José Mindlin (USP).

Disponível em: http://www.bbm.usp.br/ acesso em 05/09/2015.

Outro problema imerso nesse mundo do trabalho que se formara na cidade, era a necessidade de uma mão de obra especializada, mas como domar, como adestrar os indígenas? Para se formar era preciso educar e para educar exigia certa (trans) formação do grande contingente de indígenas que por aqui estavam.

\footnotetext{
44 SONTAG, Susan. "A Caverna de Platão." In: Sobre Fotografia. São Pulo: Companhia das Letras, 2004.

${ }^{45}$ Ainda utilizando as ideias de Susan Sontag, entendemos ponto de fuga como sendo o que se diferencia daquilo que se observa, ou seja, nas fotos que apresentamos antes de vermos o belo e o imponente, partimos nossa visão a partir das pessoas presentes nelas, que em sua maioria eram certamente trabalhadores citadinos.
} 


\section{CONSIDERAÇÕES FINAIS}

Trabalhamos a cidade estabelecendo um paralelo entre a visão do fausto, com a visão mais particular que eram as vivências dos habitantes da cidade, aqueles que aqui estavam e observavam, vivenciando e atuando no cotidiano. Nossa leitura embora tenha comportado a leitura da cidade foi uma leitura da cidade por seus habitantes, ou por aqueles que direta ou indiretamente participaram dela. Esses são os jornalistas, os diretores das obras públicas, os fotógrafos, e é claro os trabalhadores e os indígenas. Também optamos por ler a cidade pelo fato que se tratando da Belle Époque, a ideia e o valor de urbano recebe uma dimensão de muito foco em corpus de analises de diversas vertentes de ciências humanas e sociais.

Os índios de Manáos durante a Província, optaram por fazer uma invenção do cotidiano onde passaram a exercer sua prática social na lógica do poder dominante. Escrever uma história na perspectiva de baixo é importante, visto que ainda há muito a ser encarado sobre a história da cidade. Nessa perspectiva, tentamos evidenciar a cidade a partir de pessoas comuns, ordinárias que mesmo impedidas de se manifestar, estavam resistindo silenciosamente diversas vezes e se encontravam na cidade exercendo seus fazeres e saberes.

O índio passou a ser trabalhador urbano, porém ocupando ofícios inferiores, quase sem ascendência social, devido ao status de sua etnia, por isso, concordo que etnia, é um conceito hierarquizado, agora como trabalhadores passaram a ser vistos como "seres sujos", que deveriam ser afastados da urbe. Mas o índio resiste, uma prática constante dos índios que formavam a classe trabalhadora, era o abandono de seus trabalhos sem ao menos requerer salários e pagamentos que eram seus por direito. Ao passar a integrar a classe trabalhadora, o indígena estava atuando no mundo do branco, mas, com fins próprios, possivelmente ao serem trabalhadores, os indígenas também passaram a se organizar como grupo de atuação pertencendo a sindicatos e reuniões organizadas por líderes trabalhistas. 